\title{
Demola Co-creation Approach: The Students' Perspective
}

Cláudia S. Costa ${ }^{1}$, Fernando Pereira ${ }^{2}$, Inês Barbedo ${ }^{3}$, João P. Almeida ${ }^{4}$, Juliana Almeida-de-Souza ${ }^{5}$, Paula Cabo ${ }^{5}$, Pedro Rodrigues ${ }^{3}$, Rui Ferreira ${ }^{3}$, Vera FerroLebres ${ }^{5}$, Ville Kairamo ${ }^{6}$.

${ }^{1}$ CITUR, Instituto Politécnico de Bragança, Portugal, ${ }^{2} \mathrm{CIIE}$, Instituto Politécnico de Bragança, Portugal, ${ }^{3}$ Instituto Politécnico de Bragança, Portugal, ${ }^{4}$ CeDRI, Instituto Politécnico de Bragança, Portugal, ${ }^{5} \mathrm{CIMO}$, Instituto Politécnico de Bragança, Portugal, ${ }^{6}$ Demola Global, Finland.

\begin{abstract}
On the wings of New Public Management (NPM) and the Bologna Process, Higher Education Institutions (HEI) needed to innovate towards market orientation, both students demanding and social relevance. One way to achieve these objectives is through co-creation processes, involving students and partners outside as companies and public institutions. The purpose of this paper is to assess the satisfaction of Instituto Politécnico de Bragança (IPB) students who actively participated in a co-creation process called Demola, which aims the pedagogical innovation and strengthening the link with and the community. Quantitative data was collected through an online survey that included questions about students' perception on the impact of the co-creation process Demola. The population is 250 students who participated in eight batches in the last four years, working in 44 co-creation cases or challenges. 87 students answered the questionnaire, corresponding to $34,8 \%$ of the sample. Main results and conclusions suggested high levels of satisfaction among IPB students' and are perceived as having very positive impact in skills' development.
\end{abstract}

Keywords: Innovation; co-creation; higher education institutions; pedagogical innovation. 


\section{Introduction}

The spread of the NPM paradigm, from the late 1970s onward, saw the growth of a new discourse of public administration management (Hood, 1991; Broucker, \& De Wit, 2015), suggesting functioning in a quasi-business manner with market orientation and frequent customer satisfaction surveys and performance assessments (Diefenbach, 2009). HEI were also influenced by the movement of NPM (Broucker, \& De Wit, 2015).

The Bologna Process and the "European Commission has put forward a clear vision for the governance of European Universities, which includes, among other things, a diversification of funding sources, an intensification of ties between universities and industries and a closer match between the supply of qualifications and labor market demands" (Dobbins, Knill, \& Vögtle, 2011, p.666). The same authors (2011, p.666) refer that "result of transnational pressures and domestic exigencies, national systems of Higher Education (HE) governance are, to a greater or lesser degree, being reshaped, transformed, modernized and in many cases "marketized",".

Meanwhile, as part of the process, "students have begun to show interest in adopting active and participatory roles that allow them to interact and work collaboratively with educators" (Dziewanowska, 2017, p.210). Dziewanowska (2017) pointed out that students and professors play the two main roles in higher education service value co-creation process, thus resource integration is largely an interaction process between and among the parties.

HEI continuously invest in innovation, future orientation and knowledge transfer, what can benefit stakeholders, however this relation tends to be unidirectional in what knowledge is concerned. Co-creation processes between HEI and external organizations are still scarce, but if correctly implemented can concretize an opportunity to generate value for those directly involved and other stakeholders. In this sense, co-creation can be described as a "collaborative creation of value by the company and the customer" (Prahalad \& Ramaswamy, 2004, p.8). This is operationalized in a co-creative customer experience, where the customer is actively involved and contributing in some way in the design, delivery, and creation of the customer experience. "This concept is an emerging one that has been discussed intensively in various industries" (Saragih, 2019, p.466).

The introduction of co-creation processes as learning process in HEI makes "fundamental to analyze and study students' satisfaction", as previously suggested to other changing processes in HEI (Alves \& Raposo, 2007, p.1262). These authors suggested that the "image" of HEI has the biggest influence in satisfaction, namely in aspects as student's expectations, the quality perceived or value perceived, student loyalty and student's involvement in positive word-of-mouth actions. HEI are "becoming increasingly aggressive in their marketing activities" to communicate an image that is favorable to students, employers and society" (Ivy, 2001, p.276). 
Demola is an international co-creation platform operated by Demola Global and partner academic institutions together. The idea is to build multidisciplinary teams of the most motivated higher-education students and combine the insights from these teams with expert facilitator know-how to create visions of the future and competitive advantage for the participants and partner organizations. By building a bridge between the decision-makers of yesterday, today, and tomorrow, Demola drives improved and more democratized ability to react to changes as a society. Demola co-creation model and thematic areas are in line also with Sustainable Development Goals and European Commission's European Skills Agenda for sustainable competitiveness, social fairness, and resilience.

This paper aims to study students' satisfaction and perception of the impact of co-creation projects as part of their learning curriculums in IPB. The paper proceeds as follows. After this introduction and theoretical parts, the second section presents the methods and the third section the preliminary results. We concluded with discussions and main conclusions.

\section{Methods}

Quantitative data was collected through a survey specifically designed for the purpose of this study. The survey included questions about students' satisfaction and perception on the impact of the co-creation process, such as i) Overall assessment of activities; ii) Perception of worthiness of participation; iii) Perception of change in attitude towards new challenges; iv) Perception of change in attitude towards entrepreneurship; v) Perception of improvement in the ability to work in a multidisciplinary and multicultural team; vi) Perception of improvement in initiative and project management skills; vii) Perception of improvement of creativity skills; viii) Perception of improvement of technical skills; and ix) Recommendation of the project to friends. Answers were given in a Likert scale. For items i) to viii) we define a scale with 4 points (1- not productive at all to 4 - very productive) and for last item we define a scale with 10 points ( 1 - never to 10 - definitely yes). The survey was distributed between December 2020 and February 2021 to students enrolled in 8 batches of co-creation projects occurred between 2017 October and 2021 February. The online survey ensured the confidentiality of data. The participation was voluntary and after academic assessment, ensuring students that participation would not affect any grades.

\section{Results}

The study comprised a sample with a total of 87 students, with a mean age of $25,4(\mathrm{SD}=4,56)$, from 19 different nationalities. The sample included 33 females $(37,9 \%)$ and 54 males $(62,1 \%)$ students. Considering the European Qualifications Framework (EQF), this sample has $68(78,2 \%)$ bachelor students (level 6 EQF), 18 (20,7\%) master students (level 7 EQF) and $1(1,1 \%) \mathrm{PhD}$ student (level $8 \mathrm{EQF})$. Attending the academic studies, this sample 
comprise by increasing order: one student $(1,1 \%)$ from Health and Social Protection; three students $(3,4 \%)$ from Tourism, Sport and Leisure; four students $(4,6 \%)$ from Agricultural Sciences and Natural Resources; six students (6,9\%) from Education and Teacher Training, 15 students (17,2\%) from Arts, Communication and Multimedia, 16 students (18,4\%) from Business Sciences and Law and 42 students (48,3\%) from Technologies. As we can see, the Demola project is very multidisciplinary and multicultural.

Table 1. Descriptive Analysis of Students' Satisfaction.

\begin{tabular}{|c|c|c|c|c|c|c|c|}
\hline & \multirow[b]{2}{*}{$\begin{array}{c}\text { Mean } \\
(\text { SD) } \\
\mathbf{n}=87\end{array}$} & \multicolumn{2}{|c|}{ Gender } & & \multicolumn{2}{|c|}{ Participation } & \multirow[b]{2}{*}{$p$-value } \\
\hline & & $\begin{array}{c}\text { Male } \\
\text { Mean } \\
\text { (SD) } \\
\mathrm{n}=54\end{array}$ & $\begin{array}{c}\text { Female } \\
\text { Mean } \\
(\text { SD) } \\
\mathbf{n}=\mathbf{3 3} \\
\end{array}$ & $p$-value & $\begin{array}{c}\text { One } \\
\text { Mean } \\
(\text { SD) } \\
\text { n=68 }\end{array}$ & $\begin{array}{l}>\text { One } \\
\text { Mean } \\
(\text { SD) } \\
\text { n=19 }\end{array}$ & \\
\hline $\begin{array}{l}\text { How do you assess the activities } \\
\text { taken during Co-Creation } \\
\text { sessions? (1-4) }\end{array}$ & $\begin{array}{c}3,43 \\
(0,60)\end{array}$ & $\begin{array}{c}3,4 \\
(0,60)\end{array}$ & $\begin{array}{c}3,5 \\
(0,62)\end{array}$ & 0,683 & $\begin{array}{c}3,5 \\
(0,56)\end{array}$ & $\begin{array}{c}3,3 \\
(0,75)\end{array}$ & 0,563 \\
\hline $\begin{array}{l}\text { Do you think it was worth } \\
\text { participating? (1-4) }\end{array}$ & $\begin{array}{c}3,7 \\
(0,65)\end{array}$ & $\begin{array}{c}3,6 \\
(0,73)\end{array}$ & $\begin{array}{c}3,8 \\
(0,46)\end{array}$ & 0,224 & $\begin{array}{c}3,8 \\
(0,63)\end{array}$ & $\begin{array}{c}3,5 \\
(0,70)\end{array}$ & 0,078 \\
\hline $\begin{array}{l}\text { Do you consider that having } \\
\text { participated in Co-Creation } \\
\text { projects changed your attitude } \\
\text { towards new challenges? }(1-4)\end{array}$ & $\begin{array}{c}3,4 \\
(0,71)\end{array}$ & $\begin{array}{c}3,4 \\
(0,79)\end{array}$ & $\begin{array}{c}3,4 \\
(0,56)\end{array}$ & 0,547 & $\begin{array}{c}3,4 \\
(0,72)\end{array}$ & $\begin{array}{c}3,4 \\
(0,69)\end{array}$ & 0,908 \\
\hline $\begin{array}{l}\text { Co-Creation contribution to } \\
\text { entrepreneurship, emergence of } \\
\text { new business ideas. (1-4) }\end{array}$ & $\begin{array}{c}3,4 \\
(0,74)\end{array}$ & $\begin{array}{c}3,4 \\
(0,80)\end{array}$ & $\begin{array}{c}3,4 \\
(0,61)\end{array}$ & 0,957 & $\begin{array}{c}3,4 \\
(0,76)\end{array}$ & $\begin{array}{c}3,3 \\
(0,65)\end{array}$ & 0,251 \\
\hline $\begin{array}{l}\text { Co-Creation contribution to } \\
\text { improving the ability to work in } \\
\text { a multidisciplinary and } \\
\text { multicultural team (1-4) }\end{array}$ & $\begin{array}{c}3,6 \\
(0,57)\end{array}$ & $\begin{array}{c}3,6 \\
(0,62)\end{array}$ & $\begin{array}{c}3,6 \\
(0,49)\end{array}$ & 0,700 & $\begin{array}{c}3,7 \\
(0,56)\end{array}$ & $\begin{array}{c}3,5 \\
(0,61)\end{array}$ & 0,314 \\
\hline $\begin{array}{l}\text { Co-Creation contribution to the } \\
\text { development of initiative and } \\
\text { project management capacity. } \\
(1-4)\end{array}$ & $\begin{array}{c}3,5 \\
(0,64)\end{array}$ & $\begin{array}{c}3,4 \\
(0,66)\end{array}$ & $\begin{array}{c}3,6 \\
(0,61)\end{array}$ & 0,268 & $\begin{array}{c}3,5 \\
(0,61)\end{array}$ & $\begin{array}{c}3,3 \\
(0,73)\end{array}$ & 0,165 \\
\hline $\begin{array}{l}\text { Co-Creation contribution to the } \\
\text { development of creativity skills } \\
\text { (1-4) }\end{array}$ & $\begin{array}{c}3,4 \\
(0,69)\end{array}$ & $\begin{array}{c}3,4 \\
(0,69)\end{array}$ & $\begin{array}{c}3,5 \\
(0,71)\end{array}$ & 0,929 & $\begin{array}{c}3,5 \\
(0,63)\end{array}$ & $\begin{array}{c}3,2 \\
(0,85)\end{array}$ & 0,148 \\
\hline $\begin{array}{l}\text { Co-Creation contribution to the } \\
\text { development of technical skills. } \\
(1-4)\end{array}$ & $\begin{array}{c}3,1 \\
(0,86)\end{array}$ & $\begin{array}{c}3,1 \\
(0,96)\end{array}$ & $\begin{array}{c}3,2 \\
(0,66)\end{array}$ & 0,559 & $\begin{array}{c}3,1 \\
(0,86)\end{array}$ & $\begin{array}{c}3,3 \\
(0,87)\end{array}$ & 0,377 \\
\hline $\begin{array}{l}\text { Would you recommend a Co- } \\
\text { Creation experience to friends } \\
\text { and colleagues? }(1-10)\end{array}$ & $\begin{array}{c}8,8 \\
(1,70)\end{array}$ & $\begin{array}{c}8,4 \\
(1,88)\end{array}$ & $\begin{array}{c}9,3 \\
(1,21)\end{array}$ & 0,009* & $\begin{array}{c}8,9 \\
(1,47)\end{array}$ & $\begin{array}{c}8,2 \\
(2,29)\end{array}$ & 0,138 \\
\hline
\end{tabular}

* The Mann-Whitney test $(p=0,05)$ was performed to test equality of means. Source: Own Elaboration.

The assessment of how much was worthwhile participating was scored with $3,7+/-0,65$ out of 4 points. The perception of contribution of co-creation projects to the development of 
several skills was in all cases assessed over 3 in a 4 points scale, with the highest assessment for the co-creation contribution to the improvement of the ability to work in a multidisciplinary and multicultural team rated with $3,6+/-0,57$ points, and the lowest for the co-creation contribution to the development of technical skills $3,1+/-0,86$ points. The overall sample reported high rates of satisfaction assessed by the level of recommendation to friends $(8,8+/-1,70$ out of 10$)$ (Table 1$)$.

Students' satisfaction and perception on the impact of the co-creation process did not differ significantly among genders, with exception for the level of recommendation of the CoCreation experience to friends and colleagues, with females recommending significantly more $(p$-value $=0,009)$ than males, respectively 9,3 against 8,4 (Table 1$)$.

From all respondents, $19(21,9 \%)$ participated twice or more in co-creation projects. Analyzing the differences in students' satisfaction and perception on the impact of the cocreation process did not differ significantly among different participation frequency (Table $1)$.

\section{Discussion \& Conclusions}

The recommendation of this process is one of the measures of HEI student satisfaction, as previous authors already claimed in the context of HI. Ueda \& Nojima (2012) confirmed that students with higher levels of satisfaction will speak positively about their experiences and recommend to friends and family and care about the HEI reputation (Sutarso, Halim, Balqiah, \& Tjiptoherijanto, 2017).

This study shows that IPB students' satisfaction level with co-creation projects is high. This conclusion is reinforced by the perception of high impact of co-creation projects in skills development. Previous studies about co-creation projects also report high levels of satisfaction (Ribes-Giner, Perello-Marín, \& Díaz, 2016) and skills development (Yeo, 2009). One study developed in Indonesia concluded that co-creation is related to a stronger attachment of students to HEI and higher value of student experience, and that even if cocreation does not directly affect student satisfaction, it does indirectly as it affects experience value (Gunarto, \& Hurriyati, 2020). If the value of experience is higher, student satisfaction will also be higher. These results are very important if we consider that student satisfaction mediates the relationship between the antecedent variables of perceived university reputation and competency, and student citizenship behavior (Elsharnouby, 2015), contributing to a better society. In fact, HEI are looking for innovative ways to improve student satisfaction, and co-creation projects have consistently, in several studies, showed favorable effects in terms of satisfaction, trust, and loyalty, it is a pragmatic tool to be considered and implemented in HEI, so we need to foment and explore methodologies for applying these 
projects in order to increase the level of retention, word of mouth, and student loyalty (Pantoja Díaz, Ribes-Giner, \& Perello-Marin, 2016).

Students' satisfaction and skills development, as pointed out by Yeo (2009) seem to be higher in co-creation activities, hands-on, multidisciplinary and collaborative projects (Al-Sheeb, Hamouda, \& Abdella, 2018), when compared with traditional teaching (Kastolani, Arenggoasih, Indah, \& Susilayati, 2020). All skills development variables are highly scored, but the highest scoring was given to the development of skills to work in multidisciplinary teams.

No differences among genders were identified in skills development perception, which is aligned with previous studies regarding higher education students (Ain, Sabir, \& Willison, 2019). Gender differences however exist in satisfaction measured by likelihood in recommendation. Females seems to be more likely to recommend co-creation projects to friends than males, what can be a result of learning strategies differences between genders. In the past it has been suggested that male gender showed a greater preference than female gender for the abstract conceptualization mode of learning, while female gender preferred hands-on experiences and learning for the sake of the learner (Severiens, \& Ten Dam, 1994).

This result may be related to the skills not stimulated in females in regular teaching approaches, e.g., analyzing and synthesizing skills. The same authors also indicate that this incomplete skills set may lead to lower employer satisfaction with graduate skills (Ain, Sabir, \& Willison, 2019). Co-creation projects seem to be perceived as interesting, useful and skills enhancement tools, regardless the number of participations. We assume that the fact that each participation involves different challenges and different teams, novelty is maintained, and skills are always improved, characteristic also enhanced by other authors (González García, Pastor Pérez, Girona Campillo, Merino Rubio, \& Palou Vives, 2017).

We can conclude that co-creation projects produce high levels of satisfaction among students and are perceived as having very positive impact in skills' development. Future work is still necessary to understand the satisfaction and impact of results in HEI and stakeholders, as well as in lectures/facilitators and companies and public institutions members of teams. It will be useful and timely to deepen our understanding of how we must change HEI policies accelerating the move from rigid value chains to newer ones, with the objective of materializing and concretely practicing the co-creation approach.

\section{References}

Ain, C. T., Sabir, F., \& Willison, J. (2019). Research skills that men and women developed at university and then used in workplaces. Studies in Higher Education, 44(12), 23462358. 
Al-Sheeb, B., Hamouda, A. M., \& Abdella, G. M. (2018). Investigating determinants of student satisfaction in the first year of college in a public university in the state of Qatar. Education Research International, 2018(7194106), 1-14.

Alves, H., \& Raposo, M. (2007). Conceptual model of student satisfaction in higher education. Total Quality Management, 18(5), 571-588.

Broucker, B., \& De Wit, K. (2015). New public management in higher education. In The Palgrave international handbook of higher education policy and governance (pp. 57-75). Palgrave Macmillan, London.

Diefenbach, T. (2009). New public management in public sector organizations: the dark sides of managerialistic 'enlightenment'. Public administration, 87(4), 892-909.

Dobbins, M., Knill, C., \& Vögtle, E. M. (2011). An analytical framework for the crosscountry comparison of higher education governance. Higher education, 62(5), 665-683.

Dziewanowska, K. (2017). Value types in higher education-students' perspective. Journal of Higher Education Policy and Management, 39(3), 235-246.

Elsharnouby, T. H. (2015). Student co-creation behavior in higher education: The role of satisfaction with the university experience. Journal of Marketing for Higher Education, 25(2), 238-262.

González García, L., Pastor Pérez, L., Girona Campillo, C., Merino Rubio, M., \& Palou Vives, M. I. (2017). Challenge-Based Learning design in higher education: A new context for learning beyond competency approach. European Distance and E-Learning Network (EDEN) Conference Proceedings, 1, 16-20.

Gunarto, M., \& Hurriyati, R. (2020). Creating Experience value to build student satisfaction in higher education. arXiv preprint arXiv:2006.09846.

Hood, C. (1991). A public management for all seasons?. Public administration, 69(1), 3-19.

Ivy, J. (2001). Higher education institution image: a correspondence analysis approach. International Journal of educational management, 15(6), 276-282.

Kastolani, Arenggoasih, R. W., Indah, S. N., \& Susilayati, M. (2020). Implementation of cocreation by using students' mastery of 10 skills as a new product in higher education 4.0. Humanities \& Social Sciences Reviews, 8(4), 158-171.

Pantoja Díaz, O., Ribes-Giner, G., \& Perello-Marin, M. R. (2016). The impact of cocreation on the student satisfaction: Analysis through structural equation modeling. Abstract and Applied Analysis, 2016(3729791), 1-10.

Prahalad, C., \& Ramaswamy, V. (2004). Co-creation experiences: The next practice in value creation. Journal of interactive marketing, 18(3), 5-14.

Ribes-Giner, G., Perello-Marín, M. R., \& Díaz, O. P. (2016). Co-creation impacts on student behavior. Procedia-Social and Behavioral Sciences, 228, 72-77.

Saragih, H. (2019). Co-creation experiences in the music business: a systematic literature review, Journal of Management Development, Vol. 38 No. 6, pp. 464-483.

Severiens, S. E., \& Ten Dam, G. T. (1994). Gender differences in learning styles: A narrative review and quantitative meta-analysis. Higher education, 27(4), 487-501. 
Sutarso, Y., Halim, R. E., Balqiah, T. E., \& Tjiptoherijanto, P. (2017). The role of co-creation activities, trust and gender on higher education marketing performance. European Research Studies Journal, 20(3A), 825-845.

Ueda, Y., \& Nojima, M. (2012). Effect of student attitudes on university loyalty and university cooperation: an empirical study in Japan. International Journal of Management, 29(1), 133-142.

Yeo, R. K. (2009). Service quality ideals in a competitive tertiary environment. International Journal of Educational Research, 48(1), 62-76. 